\title{
Effects of UV-B radiation on Lecanicillium spp., biological control agents of the coffee leaf rust pathogen
}

\author{
José A. H. Galvão ${ }^{1}$ \& Wagner Bettiol ${ }^{2}$ \\ ${ }^{1}$ Departamento de Proteção Vegetal, UNESP/FCA, Cx. Postal 237, 18610-307, Botucatu, SP, Brazil; ${ }^{2}$ Embrapa Meio- \\ Ambiente, Cx. Postal 69, 13820-000, Jaguariúna, SP, Brazil
}

Author for correspondence: Wagner Bettiol, e-mail: wagner.bettiol@embrapa.br

\begin{abstract}
Coffee leaf rust is the main disease of coffee and its causal agent is naturally hyperparasited by Lecanicillium lecanii, indicating its potential for biocontrol. Ultraviolet-B (UV-B) radiation is an important factor that interferes on application of biocontrol agents, and Lecanicillium can be affected by UV-B. The objective of this work was to evaluate the effects of UV-B on Lecanicillium isolates and on its capacity to colonize rust lesions. There were variations among Lecanicillium strains in sensitivity to UV-B radiation, causing inactivation and delayed spore germination. The most tolerant strain (CCMA-1143) had $\mathrm{LD}_{50}=1.63 \mathrm{~kJ} / \mathrm{m}^{2}$ of UV-B. The incidence and colonization of Lecanicillium on coffee leaf rust lesions were influenced by the dose of UV-B radiation, and were increased when the isolate CCMA-1143 was sprayed on rust lesions. The effects of UV-B should be considered on efficacy studies for the development of biopesticides.
\end{abstract}

Key words: Climate change, UV-B, Hemileia vastatrix, biopesticide.

\section{INTRODUCTION}

Coffee has great importance to the Brazilian economy. Brazil is the largest producer and exporter of coffee, with a planted area of 2.3 million ha. In 2012, the production was 50.8 million bags of $60 \mathrm{~kg}$ (CONAB, 2014). Coffee leaf rust, the most important disease to this crop, caused by Hemileia vastatrix, is controlled with the application of fungicides (Maffia et al., 2009). However, the intense use of fungicides negatively impacted the environment (Pal \& Gardener, 2006; Lopes, 2009) leading to an urgent need to develop alternative methods to control the disease. According to Haddad et al. (2009), the use of biological control agents is one alternative. Lecanicillium lecanii (sin. Verticillium lecanii, Verticillium hemileiae), which can be found naturally hyperparasiting uredinospores of $H$. vastatrix in coffee rust lesions (Shaw, 1988; Vandermeer et al., 2009) among others (Spencer \& Atkey, 1981; Leinhos \& Buchenauer, 1992), may be considered a biological control agent. The role of this antagonist in the reduction of coffee leaf rust was also observed by Jackson et al. (2012).

Lecanicillium lecanii is a biocontrol agent of rust diseases and insects. However, may be less its efficiency may be reduced in the field or greenhouse due to solar UV radiation, which is harmful to several biological control agents. Ultraviolet radiation can be classified in UV-C (100-280 $\mathrm{nm})$, UV-B (280-315 nm) and UV-A (315-400 nm). UV-C radiation is completely filtered by the ozone layer and absorbed by other atmospheric gases (Kuluncsics et al. 1999). UV-B and UV-A radiations can cause cellular membrane disorganization, protein denaturation, oxidative stress, and damage to DNA, RNA, and ribosomes (Griffiths et al., 1998), and possibly cause damage to several organisms, such as plant pathogens, insects pests, plants and beneficial organisms, impacting the agroecosystems (Caldwell et al., 2003). UV-A and UV-B radiation can inactivate the structures of biological control agents due to genetic and morphological changes, resulting in lower efficacy of the biocontrol agent (Braga et al., 2001c), and is considered one of the main limitations for applying these organisms in the field (Braga et al., 2001b; Costa et al., 2012; Costa et al., 2013).

The effects of UV-B radiation on biocontrol agents have been studied for Clonostachys rosea, biocontrol agent of Botrytis cinerea (Costa et al., 2012; Costa et al. 2013), the causal agent of gray mold; and Metarhizium anisopliae, which is used to control insect pests in several crops (Braga et al., 2001bd; Rangel et al., 2005). Costa et al. (2012) observed that $C$. rosea isolates showed different sensitivities to UV-B radiation. Braga et al. (2001d), Rangel et al. (2004) and Rangel et al. (2006) observed high phenotypic plasticity of $M$. anisopliae to UV-B radiation, according to the growth media and geographical origin of the isolate.

UV-B radiation has harmful effects to host plants, pathogenic organisms, and on plant-pathogen interactions (Ghini et al., 2012). UV-B radiation reduced the ability of $C$. rose $a$ to control $B$. cinerea, and the presence and sporulation of $C$. rosea on strawberry leaf discs was influenced by the dose of UV-B radiation (Costa et al., 2013).

Little is known on the effect of UV-B radiation on biocontrol agents and considering the importance of this factor on the efficacy of antagonistic and the growing market of the biopesticides in Brazil (Bettiol, 2011) and other 
countries, the objectives of this work was to evaluate the effects of UV-B radiation on several isolates of Lecanicillium, including their capacity to colonize coffee leaf rust lesions.

\section{MATERIAL AND METHODS}

\section{Isolates and inocula preparation}

Nine isolates of L. lecanii and one isolate of Lecanicillium longisporum obtained from different regions in Brazil were used in this study (Table 1). The isolates were deposited in the collection of microorganisms of Embrapa Meio-Ambiente. Isolates were grown on potato-dextroseagar (PDA) (Acumedia) $+1 \mathrm{~g} / \mathrm{L}$ of streptomycin sulfate (Sigma) in plates of polystyrene $(50 \times 10 \mathrm{~mm})$ and incubated at $22 \pm 1^{\circ} \mathrm{C}$ and $12 \mathrm{~h} \mathrm{light} / 12 \mathrm{~h}$ dark for 7 to 10 days. In the preliminary tests to establish the appropriate irradiance and incubation period for conidia germination evaluation, the strain CCMA-1144 of L. longisporum was used. Conidia were suspended in distilled water with tween $80(0.01 \%$ $\mathrm{v} / \mathrm{v}$ ) and suspensions were filtered through a triple layer of sterilized cheesecloth to remove hyphal fragments and spore aggregates. The concentrations of conidia suspension were estimated by hemocytometer counts for immediate use in the irradiation and germination studies.

\section{UV-B chambers}

The irradiation experiments were conducted in chambers with four UV-B 313EL lamps (Q-lab). Twenty minutes prior to the experiments lamps were turned on resulting in a stable level of irradiation. The lamps were covered with a $0.13 \mathrm{~mm}$-thick cellulose diacetate film (Málaga Ltda.), which had a cutoff point at $290 \mathrm{~nm}$. This permitted the passage of most UV-B and UV-A (290-400 nm), but prevented exposure to UV-C $(280 \mathrm{~nm})$ and short-wavelength UV-B $(290 \mathrm{~nm})$. This film was changed every experiment. Control-plates were physically protected from radiation with aluminum foil. The temperature where the bioassays were conducted was adjusted to $22 \pm 2^{\circ} \mathrm{C}$.

The DNA-damage (cyclobutane pyrimidine dimer formation) action spectrum developed by Quaite et al.
(1992) and normalized to unity at $300 \mathrm{~nm}$ was used to calculate the weighted UV irradiances $\left(\mathrm{mW} / \mathrm{m}^{2}\right)$. We selected this spectral weighting function based on the fact that Paul et al. (1997) reviewed the spectral characteristics of nine fungal responses and concluded that this DNA damage spectrum closely approximated the fungal responses. All the light measurements were done with a spectroradiometer (Ocean Optics model USB2000 + rad) connected to a portable computer.

\section{Conidial germination}

Conidial suspension of Lecanicillium ( $20 \mu 1,10^{5}$ conidia/mL) was placed on $7 \mathrm{~mL}$-agar medium (PDA +1 $\mathrm{g} / \mathrm{L}$ of streptomycin sulfate) in polystyrene plates $(50 \times 10$ $\mathrm{mm}$ ) and immediately exposed to the UV-B radiation for evaluation of germination. Lactofenol $+0.05 \%$ tripan blue was used to interrupt conidial germination and growth of the germ tube. Observations were done in an optical microscope at $250 \times$. A total of 300 conidia per plate were evaluated and considered germinated when the germ tube was longer than the diameter of the conidia. Relative percent germination was calculated according to Braga et al. (2001a), by the following equation: relative germination $(\%)=(\mathrm{Wt} / \mathrm{Wc}) \times 100$, where $\mathrm{Wt}$ is the number of germlings at exposure time $t$ and $\mathrm{Wc}$ is the number of germlings of the control plate. The experiment was repeated three times.

\section{Irradiance and incubation period to evaluate spore ger- mination}

Conidia of strain CCMA-1144 of L. longisporum were produced and placed on PDA $+1 \mathrm{~g} / \mathrm{L}$ of streptomycin sulfate in polystyrene plates as described and exposed to 649,452 and $378 \mathrm{~mW} / \mathrm{m}^{2}$ of UV-B radiation. For this, the plates were positioned at 18,33 , and $48 \mathrm{~cm}$ from the lamps, respectively. After $2 \mathrm{~h}$ exposure, doses corresponded to $4.68,3.26$ and $2.70 \mathrm{~kJ} / \mathrm{m}^{2}$, respectively. After irradiated, Petri dishes were incubated at $22 \pm 1^{\circ} \mathrm{C}$, in the dark. Germination of conidia was evaluated at 12,24 and $36 \mathrm{~h}$ after exposure.

Previous trials with irradiance of $452 \mathrm{~mW} / \mathrm{m}^{2}$ (33 $\mathrm{cm}$ from the lamp) were done to establish the best incuba-

TABLE 1 - Origin of the Lecanicillum spp. strains used in this study.

\begin{tabular}{|c|c|c|c|}
\hline Isolate & Origin & Local & Elevation (m) \\
\hline CCMA-1144 (L. longisporum) & $\mathrm{U}$ & Vertirril (Itaforte Ltda.) & $\mathrm{Ni}$ \\
\hline CCMA-1140 (L. lecanii) & $\mathrm{U}$ & UFLA/Lavras, MG & $\mathrm{Ni}$ \\
\hline CCMA-1139 (L. lecanii) & $\mathrm{U}$ & UFV/Viçosa, MG & $\mathrm{Ni}$ \\
\hline OTC-1 (L. lecanii) & Coffee & Jaguariúna, SP & 580 \\
\hline OTC-2 (L. lecanii) & Coffee & Jaguariúna, SP & 580 \\
\hline CCMA-1142 (L. lecanii) & Coffee & Jaguariúna, SP & 580 \\
\hline CCMA-1138 (L. lecanii) & Coffee & Jaguariúna, SP & 580 \\
\hline CCMA-1141 L(L. lecanii $)$ & Coffee & Pedreira, SP & 900 \\
\hline CCMA-1143 (L. lecanii) & Coffee & Serra Negra, SP & 1050 \\
\hline SGI-01 (L. lecanii) & Coffee & Jaguariúna, SP & 580 \\
\hline
\end{tabular}

$\mathrm{U}=$ Unknown 
tion period after exposure to UV-B radiation and controls. A conidial suspension of strain CCMA-1144 was transferred to PDA $+1 \mathrm{~g} / \mathrm{L}$ of streptomycin sulfate and exposed at 0 , 15, 30, 60, 90 and $120 \mathrm{~min}$ (corresponding to 0, 0.41, 0.82, $1.63,2.45$ and $3.26 \mathrm{~kJ} / \mathrm{m}^{2}$, respectively) of UV-B radiation and then incubated at $22 \pm 1^{\circ} \mathrm{C}$ in the dark. The determination of conidia germination was done at 12, 16, 20, 24 and $36 \mathrm{~h}$ after exposure. The experiments were repeated three times.

\section{Effects of UV-B radiation on spore germination and sur- vival curve}

Once the appropriate period of incubation for germination evaluation was established, ten Lecanicillium isolates (Table 1) were compared for their tolerance to UV-B radiation. The conidial suspensions of these isolates were exposed to UV-B radiation (irradiance of $452 \mathrm{~mW} / \mathrm{m}^{2}$ ) for 0,40 and $60 \mathrm{~min}$, corresponding to $0,1.09$ and $1.63 \mathrm{~kJ} /$ $\mathrm{m}^{2}$, respectively. After exposure to UV-B, the conidia were kept at $22 \pm 1^{\circ} \mathrm{C}$ in the dark for $20 \mathrm{~h}$ and the germination was evaluated. The experiment was repeated three times.

To establish the survival curve, conidial suspensions of Lecanicillium (strains CCMA-1138, CCMA-1139, CCMA-1140, CCMA-1141, CCMA-1142 and CCMA-1143) were placed in plates containing PDA $+1 \mathrm{~g} / \mathrm{L}$ of streptomycin sulfate and were exposed to UV-B radiation (irradiance $452 \mathrm{~mW} / \mathrm{m}^{2}$ ) for $0,15,30,45,60,75$ and $90 \mathrm{~min}$, corresponding to $0,0.41,0.82,1.23,1.63,2.04$ and $2.45 \mathrm{~kJ} / \mathrm{m}^{2}$, respectively. After irradiation, the plates were incubated at $22 \pm 1^{\circ} \mathrm{C}$ in the dark for $20 \mathrm{~h}$ until the evaluation of germination. After this period lactophenol $+0.05 \%$ tripan blue was applied to evaluate germination under a microscope. The experiment was repeated three times.

To establish the most sensitive period prior to germination, conidia of strain CCMA-1143 were placed on PDA $+1 \mathrm{~g} / \mathrm{L}$ of streptomycin sulfate and incubated for $0,3,6,9$, $12,15,18$ and $21 \mathrm{~h}$ before exposure to $1.74 \mathrm{~kJ} / \mathrm{m}^{2}\left(\mathrm{LD}_{50}\right)$, corresponding to $64 \mathrm{~min}$ under UV-B radiation (irradiance $452 \mathrm{~mW} / \mathrm{m}^{2}$ ). After irradiation, plates were kept at $22 \pm 1^{\circ} \mathrm{C}$ in the dark for $20 \mathrm{~h}$ until the evaluation of germination. The experiment was repeated three times.

\section{Effects of UV-B radiation on the colonization of rust le- sions}

Leaf discs of Coffea arabica $\mathrm{L}$ cv. Mundo Novo with young sporulated lesions of coffee leaf rust were removed with a $1.5 \mathrm{~cm}$ diameter cork punch and placed into plastic boxes $(30 \times 40 \times 5 \mathrm{~cm})$. The discs were placed on a layer of $1 \mathrm{~cm}$ foam saturated with water. Using a $20 \mathrm{~mL}$ spray dispenser, $3.0 \mu 1 / \mathrm{cm}^{2}$ of the spore suspension $\left(10^{7}\right.$ spores $/ \mathrm{mL}$ ) of strain CCMA-1143 were or were not sprayed on the leaf discs and the discs were exposed to UV-B radiation (irradiance $452 \mathrm{~mW} / \mathrm{m}^{2}$ ) for 0,64 and $128 \mathrm{~min}$, corresponding to doses $0,1.74\left(\mathrm{LD}_{50}\right)$ and $3.48 \mathrm{~kJ} / \mathrm{m}^{2}$. Control discs were placed on the foam and wrapped with aluminum foil. After exposure to radiation, the boxes were covered with glass plates and maintained under $12 \mathrm{~h}$ photoperiod, 1000 lux, $26 \pm 2^{\circ} \mathrm{C}$, and approximately $100 \%$ relative humidity, for 5 days. The experiment was arranged in a randomized block design $(\mathrm{n}=4)$, with 50 leaf discs for each replication. The incidence of $L$. lecanii on lesions and percentage of the colonized area of lesions were evaluated 3,4 , and 5 days after irradiation. The Area Under Incidence of the Antagonist Progress Curve (AUIAPC) and Area Under Colonization of Antagonist Progress Curve (AUCAPC) were calculated. The experiment was repeated three times.

\section{Experimental design and data analysis}

The experiment design was completely randomized. For experiments on PDA media, there were two plates as replicates for each treatment. The data from three experimental repetitions invariably resulted in treatment effects in the same significance classes; therefore, the data were grouped for analyses. Statistical Analysis Systems (SAS Institute Inc.) was used to statistical analyses. Data for conidial germination were examined using analysis of variance (ANOVA) and treatment means were compared by Tukey test $(\alpha=0.05)$. Quantitative relationships between germination of $L$. lecanii conidia and hours of exposure after inoculation were examined by regression models. For evaluations on leaf discs, there were three replication plates each contained 50 disks. The data were analyzed using analysis of variance (ANOVA), and differences among treatments were compared by Tukey test $(\alpha=0.05)$, using SAS.

\section{RESULTS}

\section{Determination of the appropriate exposition periods and doses of radiation}

The germination of L. longisporum CCMA-1144 conidia in the control treatment was $62 \%$ after $12 \mathrm{~h}$, and $>90 \%$ after 24 and $36 \mathrm{~h}$ incubation. After $36 \mathrm{~h}$ incubation, it was impossible to count conidial germination in the control because the germ tubes were too long. For the conidia exposed to UV-B radiation $18 \mathrm{~cm}$ distant from the lamps, corresponding to $4.68 \mathrm{~kJ} / \mathrm{m}^{2}$ (irradiance $649 \mathrm{~mW} / \mathrm{m}^{2}$ ) the germination was zero for all incubation periods. Conidia submitted to UV-B $48 \mathrm{~cm}$ distant from the lamps, corresponding to $2.70 \mathrm{~kJ} / \mathrm{m}^{2}$ (irradiance $378 \mathrm{~mW} / \mathrm{m}^{2}$ ), the germination was $75 \%$ and $87 \%$ after incubation for 24 and 36 $\mathrm{h}$, respectively. The medium irradiance $(33 \mathrm{~cm}$ distant from the lamps - $452 \mathrm{~mW} / \mathrm{m}^{2}$ ) which corresponds to a final dose of $1.63 \mathrm{~kJ} / \mathrm{m}^{2}$ provided the medium lethal dose (conidia germination $6 \%$ and $40 \%$ after incubation for 24 and 36 , respectively) and this dose was selected for the next experiment.

The germination of $L$. longisporum conidia was inversely proportional to the UV-B (irradiance $452 \mathrm{~mW} / \mathrm{m}^{2}$ ) (Table 2), i.e. low conidial germination was found in the dose $>1.63 \mathrm{~kJ} / \mathrm{m}^{2}(>60 \mathrm{~min})$ and higher conidial germination was found in the dose $<0.41 \mathrm{~kJ} / \mathrm{m}^{2}(<15 \mathrm{~min}$ ) (Table 2). The exposure of $120 \mathrm{~min}\left(3.26 \mathrm{~kJ} / \mathrm{m}^{2}\right)$ was lethal for the 
Effects of UV-B radiation on Lecanicillium spp., biological control agents of the coffee leaf rust pathogen

TABLE 2 - Germination of Lecanicillium longisporum conidia exposed to UV-B radiation (irradiance $452 \mathrm{~mW} / \mathrm{m}^{2}$ ).

\begin{tabular}{|c|c|c|c|c|c|c|}
\hline \multirow{2}{*}{$\begin{array}{l}\text { Incubation } \\
\text { period }\end{array}$} & \multicolumn{6}{|c|}{ UV-B radiation ( $\mathrm{kJ} / \mathrm{m}^{2}$ and exposition time) } \\
\hline & $\begin{array}{c}0 \\
(0 \mathrm{~min})\end{array}$ & $\begin{array}{c}0.41 \\
(15 \mathrm{~min})\end{array}$ & $\begin{array}{c}0.82 \\
(30 \mathrm{~min})\end{array}$ & $\begin{array}{c}1.63 \\
(60 \mathrm{~min})\end{array}$ & $\begin{array}{c}2.45 \\
(90 \mathrm{~min})\end{array}$ & $\begin{array}{c}3.26 \\
(120 \mathrm{~min})\end{array}$ \\
\hline \multicolumn{7}{|c|}{ Germination (\%) } \\
\hline $12 \mathrm{~h}$ & $53.8 \mathrm{aB}$ & $0.0 \mathrm{bC}$ & $0.0 \mathrm{bB}$ & $0.0 \mathrm{bB}$ & $0.0 \mathrm{bA}$ & $0.0 \mathrm{bA}$ \\
\hline $16 \mathrm{~h}$ & $77.0 \mathrm{aAB}$ & $50.8 \mathrm{abB}$ & $41.2 \mathrm{bA}$ & $0.7 \mathrm{cB}$ & $4.8 \mathrm{cA}$ & $0.0 \mathrm{cA}$ \\
\hline $20 \mathrm{~h}$ & $80.2 \mathrm{aAB}$ & $71.3 \mathrm{abAB}$ & $44.5 \mathrm{bA}$ & $13.7 \mathrm{cAB}$ & $1.3 \mathrm{cA}$ & $0.0 \mathrm{cA}$ \\
\hline $24 \mathrm{~h}$ & $84.0 \mathrm{aA}$ & $70.7 \mathrm{aAB}$ & $65.8 \mathrm{aA}$ & $8.8 \mathrm{bB}$ & $1.7 \mathrm{bA}$ & $0.0 \mathrm{bA}$ \\
\hline $36 \mathrm{~h}$ & $99.7 \mathrm{aA}$ & $85.0 \mathrm{abA}$ & $62.7 \mathrm{bcA}$ & $39.1 \mathrm{cdA}$ & $13.9 \mathrm{deA}$ & $0.0 \mathrm{eA}$ \\
\hline
\end{tabular}

Means followed by the same lowercase letters in the line and the same uppercase letters in the columns do not differ significantly (Tukey test, $\alpha=0.05$ ).

conidia. The exposure of $30 \min \left(0.82 \mathrm{~kJ} / \mathrm{m}^{2}\right)$ provided the medium lethal dose and was selected for next the experiments. The most appropriate incubation period to evaluate conidia germination was between 12 to $20 \mathrm{~h}$ for the control and the irradiated treatments, respectively, and the most appropriate irradiation dose was between $0.41 \mathrm{~kJ} / \mathrm{m}^{2}(15 \mathrm{~min})$ and $1.63 \mathrm{~kJ} / \mathrm{m}^{2}$ (60 $\mathrm{min}$ ) (Table 2).

\section{Effects of UV-B radiation on spore germination and sur- vival}

There were variations among Lecanicillium strains in sensitivity to UV-B radiation. Strains CCMA-1138, CCMA-1143, CCMA-1141 and CCMA-1140 were the most tolerant, while strains CCMA-1142, OTC-2 and CCMA1144 were the most sensitive isolates to UV-B radiation. The other isolates presented an intermediate behavior (Figure 1).

Survival curves showed differences in sensitivity to UV-B radiation among the six Lecanicillium isolates tested. $\mathrm{LD}_{50}$ for the isolates, obtained by regression, ranged from $0.41 \mathrm{~kJ} / \mathrm{m}^{2}$ for strain CCMA-1142 to $1.74 \mathrm{~kJ} / \mathrm{m}^{2}$ for CCMA$1143 \mathrm{~kJ} / \mathrm{m}^{2}$ (Figure 2A).

In the bioassay to determine the most sensitive period of germination prior to exposure to UV-B radiation, conidia germination in the control treatment (without radiation) was approximately $100 \%$ in all incubation periods. The germination of conidia not incubated and irradiated (time 0 ) was approximately $50 \%$ according to expected for isolate CCMA-1143, exposed to a dose of $1.74 \mathrm{~kJ} / \mathrm{m}^{2}$ $\left(\mathrm{LD}_{50}\right)$. Incubation for 3 to $9 \mathrm{~h}$ prior to irradiation caused reduction in Lecanicillium conidia germination. When incubated for $6 \mathrm{~h}$ before irradiation nearly 100\% inhibition of conidia germination was observed. After $12 \mathrm{~h}$ or more of the incubation prior to UV-B radiation exposure, no change on germination was observed (Figure 2B).

\section{Effects of UV-B radiation on colonization of rust lesions}

The first signs of $L$. lecanii colonizing rust lesions were observed approximately $72 \mathrm{~h}$ after spraying the antagonist and exposure to UV-B radiation, in all treatments. The AUIAPCs for UV-B radiation doses $1.74 \mathrm{~kJ} / \mathrm{m}^{2}\left(\mathrm{LD}_{50}\right)$ and $3.48 \mathrm{~kJ} / \mathrm{m}^{2}$ differed significantly among the treatments with and without $L$. lecanii inoculation. The AUIAPC and AUCAPC increased when Lecanicillium isolate CCMA1143 was sprayed in coffee leaf rust lesions (Figures $3 \mathrm{AB}$ ). For the two UV-B radiation doses $\left(1.74 \mathrm{~kJ} / \mathrm{m}^{2}\right.$ and $3.48 \mathrm{~kJ} /$ $\mathrm{m}^{2}$ ) we did not observed inhibition of Lecanicillium grown on the rust. Lesions of coffee rust exposed or not to UV-B, without inoculation with Lecanicillium, showed a low AUIAPC and AUCAPC (Figure 3AB).

\section{DISCUSSION}

The harmful effects of UV-B radiation on biocontrol fungi were observed for Metarhizium anisopliae, Lecanicillium lecanii and Clonostachys rosea (Braga et al., 2001b; Braga et al., 2002; Costa et al., 2012). This radiation is biologically active against plants (Jaakola \& Hohtola, 2010), bacteria and viruses (Paul \& Gwynn-Jones, 2003), affecting the organisms and their interactions (Paul, 2000). We showed different biological effects of UV-B radiation on conidia of Lecanicillum isolates, including inactivation and delayed in germination (Table 2, and Figures 1-3). According to Braga et al. (2002), a strong negative effect of UV-B radiation on conidial culturability was observed with $V$. lecanii.

Cabrera et al. (1995) and Piazena (1996) observed higher UV-B intensity in higher altitudes. Braga et al. (2001c) discuss the differential tolerance to UV-B radiation among Metharizium isolates from different geographical areas and altitudes. Although our sampling was very limited, there is an indication that isolates obtained from higher altitudes may be more tolerant to UV-B radiation (Figures 1 and 2). Further studies are necessary to confirm this hypothesis.

UV-B radiation chamber used in the experiments was similar to the one described by Costa (2011), who observed inactivation of Clonostachys rosea and Trichoderma spp. conidia by UV-B radiation. The DNA and other macromolecules of conidia exposed to UV-B radiation may suffer damage (Kunz et al., 2006), resulting in loss of biological functions (Gerhardt et al., 1999) and delayed recovery from the damages (Braga et al., 2002).

The levels of sensitivity to UV-B radiation were different for the 10 Lecanicillium strains studied. The causes 


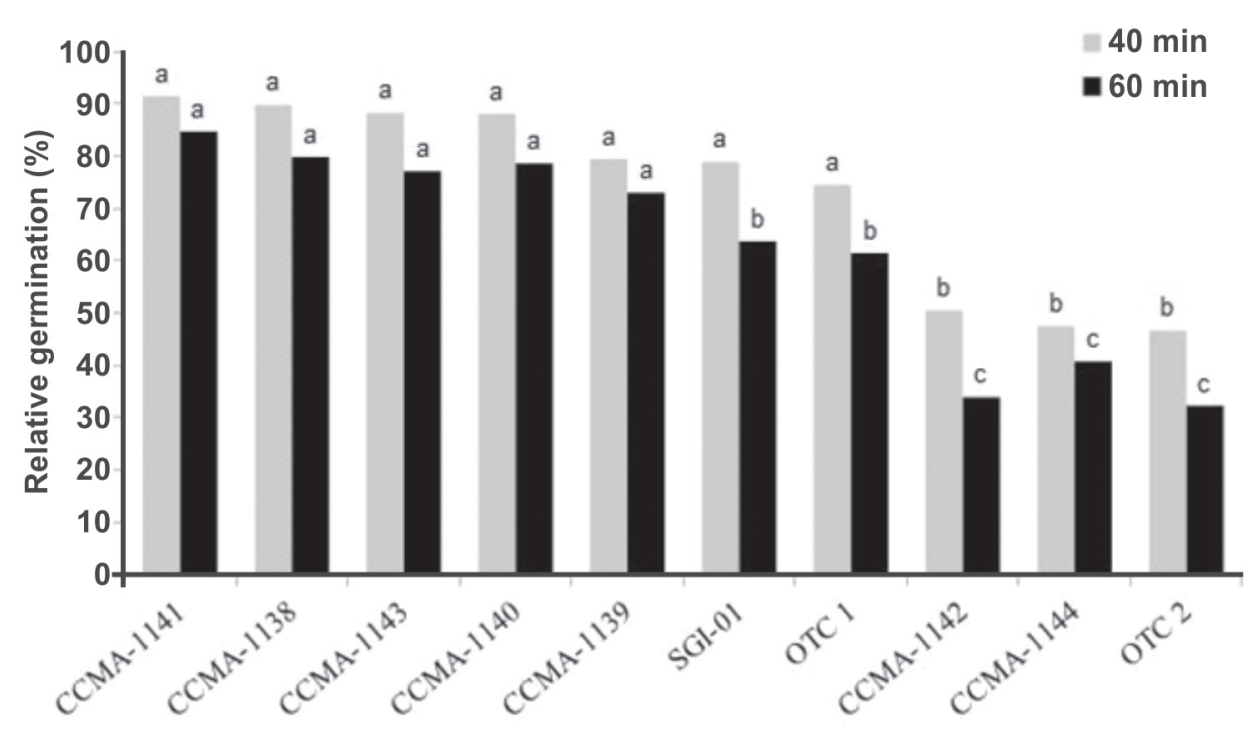

FIGURE 1 - Relative germination of Lecanicillium conidia of ten strains after exposure for 40 and $60 \mathrm{~min}$ to UV-B radiation (irradiance $452 \mathrm{~mW} / \mathrm{m}^{2}$ at a dose of $1.09 \mathrm{~kJ} / \mathrm{m}^{2}$ and $1.63 \mathrm{KJ} / \mathrm{m}^{2}$, respectively). After exposure to UV-B, the conidia were kept at $22 \pm 1^{\circ} \mathrm{C}$ in the dark for $20 \mathrm{~h}$ and the germination was evaluated. Relative germination was calculated in relation to control plates. Means followed by the same letter do not differ from each other (Scott-Knott $\alpha=0.05$ ), within the same exposure time.

for this effect may be the adaptation of the isolates to the geographic origin, with different incidences of UV-B radiation (Piazena, 1996), genetic variability (Fernandes et al., 2007) and genotypic plasticity (Braga et al. 2001a, Rangel et al. 2004; Rangel et al., 2005; Rangel et al., 2006). Fernandes et al. (2007) tested the sensitivity of 60 isolates of Beauveria spp. to UV-B radiation and the conidia germination ranged between 0 and $80 \%$. Costa (2011) exposed conidia of Trichoderma isolates to the same radiation and did not observe differences in germination among them. These results indicate that fungal species and isolates within each species have different sensitivity to UV-B radiation.

Costa et al. (2012) and Costa (2011), using approximately the same radiation of this study, found that the $\mathrm{LD}_{50}$ for Trichoderma asperellum LQC-96 and C. rosea LQC-62 were $4.9 \mathrm{~kJ} / \mathrm{m}^{2}$ and $4.1 \mathrm{~kJ} / \mathrm{m}^{2}$, respectively. We have found that for Lecanillium CCMA-1143 the $\mathrm{LD}_{50}$ was $1.63 \mathrm{~kJ} / \mathrm{m}^{2}$, indicating that it is more sensitive than the other two-biocontrol agents. Lecanicillium CCMA-1143 was also more sensitive than M. anisopliae strain ARSEF 2575 (Braga et al., 2001a). In general, $M$. anisopliae mutants with white conidia were more sensitive to simulated solar UV radiation than mutants with purple conidia, which were more sensitive than mutants with yellow conidia, which in turn were more sensitive than the green wild strain (Braga et al., 2006). Therefore, greater sensitivity of Lecanicillium to UV-B radiation is linked to the colour of their spores.

These results indicate that it is important to select strains of biocontrol agents which are more tolerant to UV-B radiation, as well as prepare formulations with capacity to increase the bioagent tolerance to radiation. Alves et al. (1998) observed that oil-based formulations for bioagents in general provide higher protection against radiation than water-based formulations.
The sensitivity of conidia germination of Lecanillium to UV-B radiation depends on the germination stage in observed the same trend they are (Figure 2B). Costa et al. (2012) obtained the same tendency for the biocontrol agent C. rosea. Braga et al. (2001a) found that UV-B distinctly affects various stages of germination of Metarhizium. This result suggests that the effect of UV-B was on the germination of conidia of Lecanicillium not on the germtube and micelial growth.

The low AUIAPC and AUCAPC observed in lesions of coffee rust exposed or not to UV-B, without inoculation with Lecanicillium, are due to natural contamination of lesions. This antagonist is found naturally hyperparasiting urediniospores of $H$. vastatrix in coffee rust lesions (Shaw, 1988; Vandermeer et al., 2009). There is also need to consider that Lecanicillium occurs naturally parasitizing other pathogenic fungi, as well as several species of insects and nematodes (Askary et al., 1998, Goettel et al., 2008; Park \& Kim, 2010).

The use of Lecanicillium isolate CCMA-1143 (the most tolerant strain selected in this study), possibly favoured the establishment of the antagonist in rust lesions when the leaf was exposed to radiation (Figure 3). However, it is important to evaluate the effects on the colonization of coffee rust lesions when using a sensitive Lecanicillium strain. Another important aspect to be considered is the sensitivity of $H$. vastatrix urediniospores to doses of UV-B radiation, because Lazzaretti et al. (2014) observed that the urediniospores germination is reduced when these are exposed to UV-B.

The UV-B radiation may have altered the communities of phylloplane microorganisms and have a regulatory role on microorganism communities associated with natural biological control of coffee leaf rust. Despite the fact that this bioagent is not yet being used commercially for 


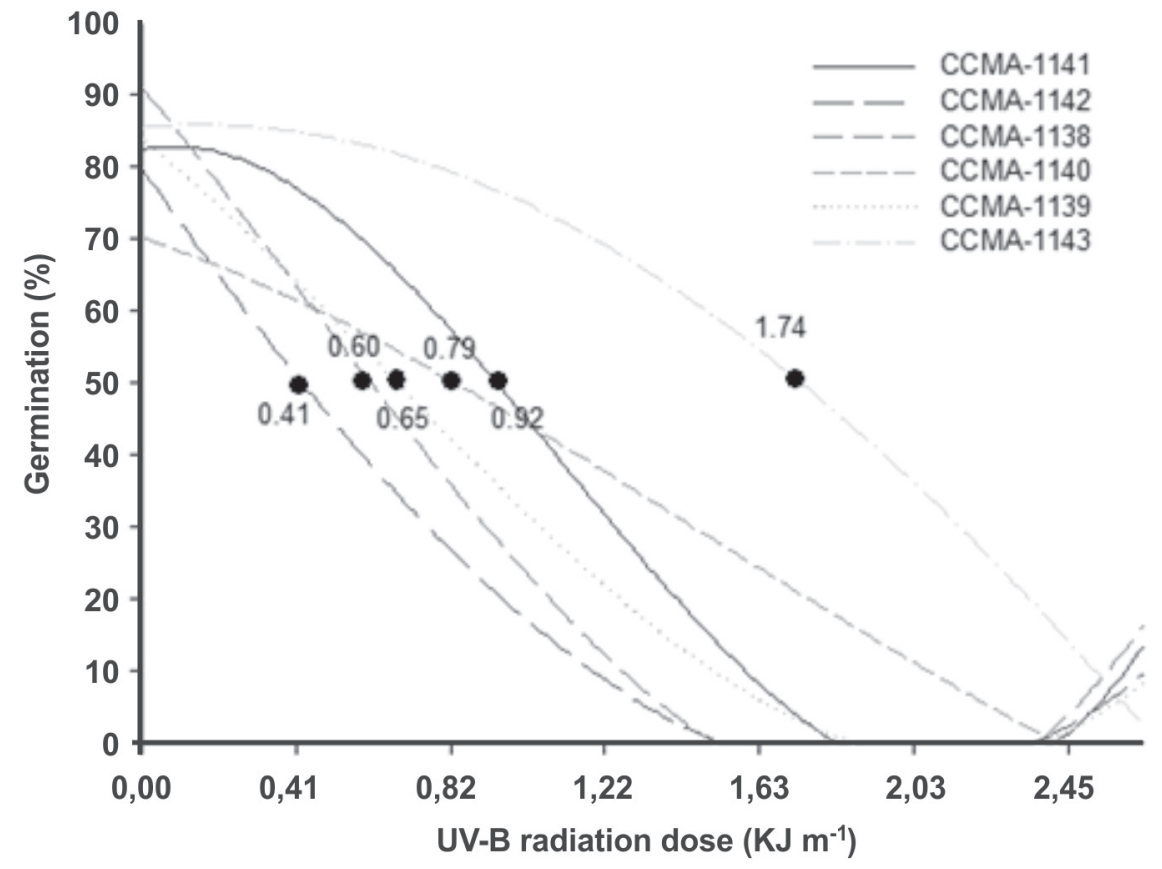

A

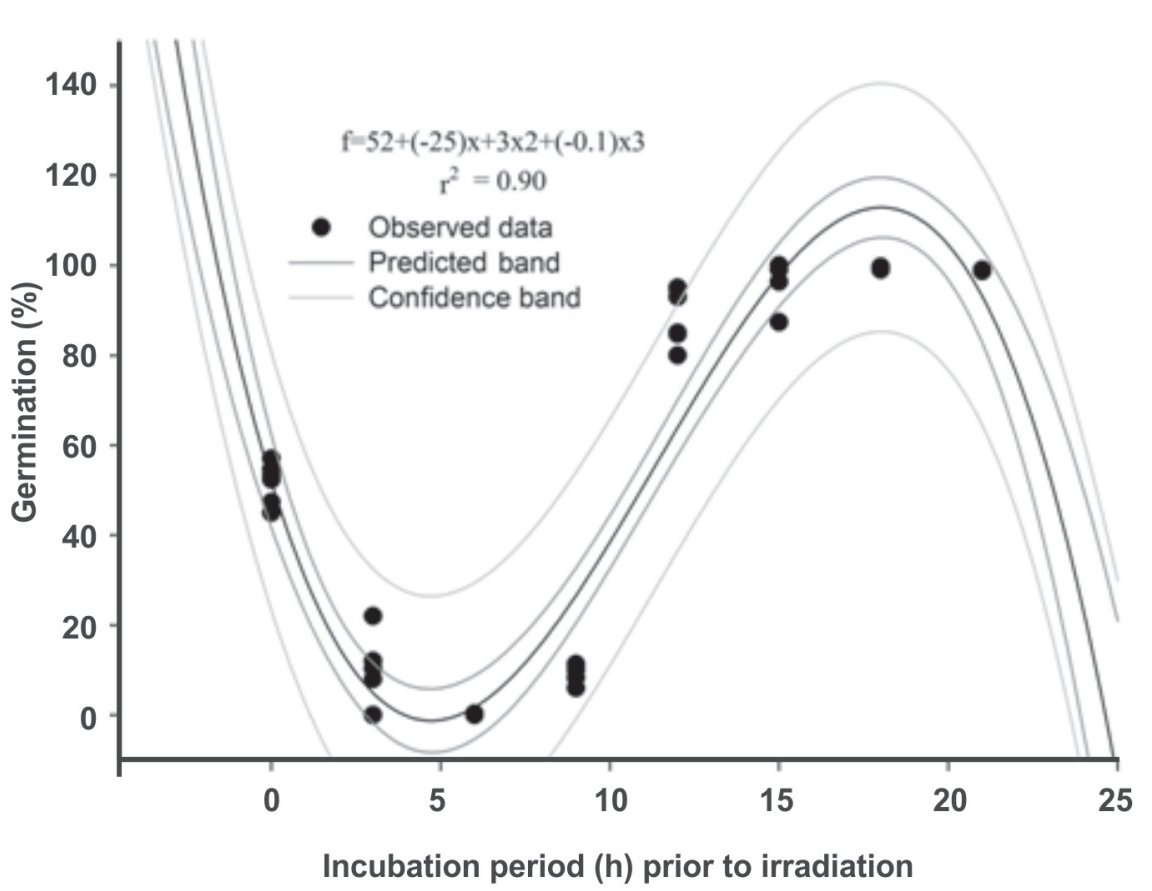

FIGURE 2 - A. Survival curve and $\mathrm{LD}_{50}$ of Lecanicillium lecanii conidia exposed to UV-B radiation on agar media to doses of UV-B radiation (irradiance of $\left.452 \mathrm{~mW} / \mathrm{m}^{2}\right)$. B. Effect of incubation $\left(22 \pm 1^{\circ} \mathrm{C}\right.$ in the dark) period for $0,3,6,9,12,15,18$ and $21 \mathrm{~h}$ of strain CCMA-1143 conidia prior to irradiation of UV-B radiation $\left[1.74 \mathrm{~kJ} / \mathrm{m}^{2}\left(\mathrm{LD}_{50}\right)\right.$, corresponding to $64 \mathrm{~min}$ ] and kept at $22 \pm 1^{\circ} \mathrm{C}$ in the dark for $20 \mathrm{~h}$ until the evaluation of germination. 

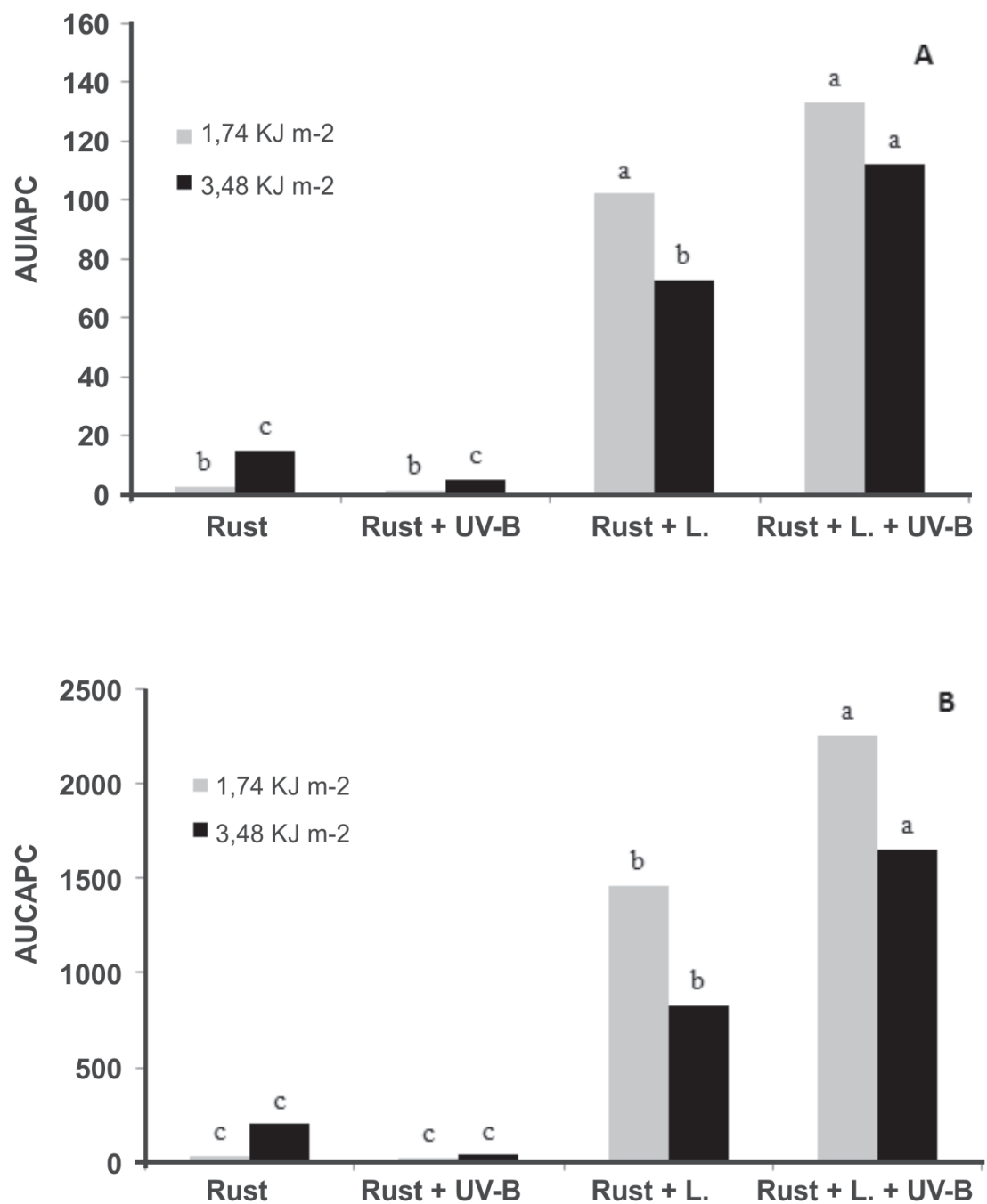

FIGURE 3 - Effect of doses 1.74 (64 $\mathrm{min})$ and $3.48 \mathrm{~kJ} / \mathrm{m}^{2}(128 \mathrm{~min})$ of UV-B radiation in the Area Under Incidence of the Antagonist Progress Curve (AUIAPC) (A) and Area Under Colonization of the Antagonist Progress Curve (AUCAPC) (B) of strain CCMA1143 of Lecanicillium lecanii on coffee leaf discs with rust lesions. Treatments: rust=leaf disc of young sporulated lesion of rust not submitted to UV-B radiation; rust $+\mathrm{UV}-\mathrm{B}=$ leaf disc of young sporulated lesion of rust submitted to $\mathrm{UV}-\mathrm{B}$ radiation; rust $+\mathrm{L}=$ rust + sprayed with conidia suspension of Lecanicillium not submitted to $\mathrm{UV}-\mathrm{B}$ radiation; rust $+\mathrm{L}+\mathrm{UV}-\mathrm{B}=$ rust + sprayed with conidia suspension of Lecanicillium submitted to UV-B radiation.

the control of coffee leaf rust, it is important to study all aspects of its bioecology, because with the possible changes in coffee and possibly other cropping systems, this antagonist may have its use expanded in the near future.

\section{ACKNOWLEDGEMENT}

The senior author acknowledges Conselho Nacional de Desenvolvimento Científico e Tecnológico - CNPq for

\section{REFERENCES}

Alves RT, Bateman RP, Prior C, Leather SR (1998) Effects of simulated solar radiation on conidial germination of Metarhizium anisopliae in different formulations. Crop Protection 17:675-679.

Askary H, Carriere Y, Belanger RR, Brodeur J (1998) Pathogenicity of the fungus Verticillium lecanii to aphids and powdery mildew. Biocontrol Science Technolology 8:23-32.

Bettiol W (2011) Biopesticide use and research in Brazil. Outlooks on Pest Management 22:280-283.

Braga GUL, Flint S, Messias CL, Anderson AJ, Roberts DW (2001a) Effect of UV-B on conidia and germlings of the entomopathogenic hyphomycete Metarhizium anisopliae. Mycological Research 105:874-882.

Braga GUL, Flint S, Messias CL, Anderson AJ, Roberts DW (2001b) Effects of UVB irradiance on conidia and germinants of the entomopathogenic hyphomycete Metarhizium anisopliae: a study of reciprocity and recovery. Photochemistry and Photobiology 73:140-146.

Braga GUL, Flint S, Miller CD, Anderson AJ, Roberts DW (2001c) Both solar UVA and UVB radiation impair conidial culturability and delay germination in the entomopathogenic fungus Metarhizium anisopliae. Photochemistry and Photobiology 


\section{4:734-739.}

Braga GUL, Flint S, Miller CD, Anderson AJ, Roberts DW (2001d) Variability in response to UV-B among species and strains of Metarhizium isolated from sites at latitudes from 61 degrees $\mathrm{N}$ to 54 degrees S. Journal of Invertebrate Pathology 78:98-108.

Braga GUL, Rangel DEN, Flint SD, Miller CD, Anderson AJ, Roberts DW (2002) Damage and recovery from UV-B exposure in conidia of the entomopathogens Verticillium lecanii and Aphanocladium album. Mycologia 94:912-920.

Braga GUL, Rangel DEN, Flint SD, Anderson AJ, Roberts DW (2006) Conidial pigmentation is important to tolerance against solar-simulated radiation in the entomopathogenic fungus Metarhizium anisopliae. Photochemistry and Photobiology 82:418-422.

Cabrera S, Bozzo S, Fuenzalida H (1995) Variations in UVradiation in Chile. Journal of Photochemistry and Photobiology 28:137-142.

Caldwell MM, Ballaré CL, Bornman JF, Flint S, Bjorn LO, Teramura AL, Kulandaivelu G, Tevini M (2003) Terrestrial ecosystems, increased solar ultraviolet radiation and interactions with other climatic change factors. Photochemistry and Photobiology 2:29-38.

CONAB - Companhia Nacional de Abastecimento. Available at: http:/www.conab.gov.br/OlalaCMS/uploads/ arquivos/13_09_09_15_34_48_boletim_cafe_-_setembro_2013. pdf. Accessed on January 2014 .

Costa LB (2011) Efeito da radiação ultravioleta-B sobre Trichoderma spp. e Clonostachys rosea, agentes de biocontrole de fitopatógenos. MS Dissertation. Universidade Federal de Lavras. Lavras, MG.

Costa LB, Rangel DEN, Morandi MAB, Bettiol W (2012) Impact of UV-B radiation on Clonostachys rosea germination and growth. World Journal of Microbiology and Biotechnology 28:24972504.

Costa LB, Rangel DEN, Morandi MAB, Bettiol W (2013) Effects of UV-B radiation on the antagonistic ability of Clonostachys rosea to Botrytis cinerea on strawberry leaves. Biological Control 65:95-100.

Fernandes EKK, Rangel DEN, Moraes AML, Bittencourt VREP, Roberts DW (2007) Variability in tolerance to UV-B radiation among Beauveria spp. isolates. Journal of Invertebrate Pathology 96:237-243.

Gerhardt KE, Wilson M, Greenbert BM (1999) Tryptophan photolysis leads to a UVB-Induced $66 \mathrm{kDa}$ photoproduct of ribulose-1,5-bisphosphate carboxyIase/oxygenase (Rubisco) in vitro and in vivo. Journal of Photochemistry and Photobiology 70:49-56

Ghini R, Hamada E, Angelotti F, Costa LB, Bettiol W (2012) Research approaches, adaptation strategies, and knowledge gaps concerning the impacts of climate change on plant disease. Tropical Plant Pathology 37:5-24.

Goettel MS, Koike M, Kim JJ, Aiuchi D, Shinya R, Brodeur J (2008) Potential of Lecanillium spp. for management of insects, nematodes and plant diseases. Journal of Invertebrate Pathology 98:256-261.

Griffiths HR, Mistry P, Herbert KE, Lunec J (1998) Molecular and cellular effects of ultraviolet light-induced genotoxicity. Critical
Reviews in Clinical Laboratory Sciences 35:189-237.

Haddad F, Maffia LA, Mizubuti ESG, Teixeira H (2009) Biological control of coffee rust by antagonistic bacteria under field conditions in Brazil. Biological Control 49:114-119.

Jaakola L, Hohtola A (2010) Effect of latitude on flavonoid biosynthesis in plants. Plant Cell and Environment 33:12391247.

Jackson D, Skillman J, Vandermeer J (2012) Indirect biological control of the coffee leaf rust, Hemileia vastatrix, by the entomogenous fungus Lecanicillium lecanii in a complex coffee agroecosystem. Biological Control 61:89-97.

Kuluncsics Z, Perdiz D, Brulay E, Muel B, Sage E (1999) Wavelength dependence of ultraviolet-induced DNA damage distribution: involvement of direct or indirect mechanisms and possible artefacts. Journal of Photochemistry and Photobiology 49:71-80.

Kunz BA, Cahill DM, Mohr PG, Osmond MJ, Vonarx EJ (2006) Plant responses to UV radiation and links to pathogen resistance. International Review of Cytology 255:1-40.

Lazzaretti GS, Rezende LC, Heck DW, Bettiol W (2014) A germinação de urediniosporos de Hemileia vastatrix é alterada pela radiação UV-B. Summa Phytopathologica 40(Suppl.):1. (Abstract)

Leinhos GME, Buchenauer H (1992) Hyperparasitism of selected fungi on rust fungi of cereal. Journal of Plant Disease and Protection 99:482-498.

Lopes RBA (2009) A indústria no controle biológico: produção e comercialização de microrganismos no Brasil. In: Bettiol W, Morandi MAB (Eds.) Biocontrole de doenças de plantas: uso e perspectivas. Jaguariúna, SP. Embrapa Meio Ambiente. pp 15-28.

Maffia LA, Haddad F, Mizubuti ESG (2009) Controle biológico da ferrugem do cafeeiro. In: Bettiol W, Morandi MAB (Eds.) Biocontrole de doenças de plantas: uso e perspectivas. Jaguariúna, SP. Embrapa Meio Ambiente pp. 267-275.

Pal, KK, Gardener BM (2006) Biological Control of Plant Pathogens. The Plant Health Instructor DOI: 10.1094/PHI-A2006-1117-02.

Park H, Kim K (2010) Selection of Lecanicillium strains with high virulence against developmental stages of Bemisia tabaci. Mycobiology 38:210-214.

Paul ND (2000) Stratospheric ozone depletion, UV-B radiation and crop disease. Environmental Pollution 108:343-355.

Paul ND, Gwynn-Jones D (2003) Ecological roles of solar UV radiation: towards an integrated approach. Trends in Ecology and Evolution 18:48-55.

Paul ND, Rasanayagam S, Moody SA, Hatcher PE, Ayres PG (1997) The role of interactions between trophic levels in determining the effects of UV-B on terrestrial ecosystems. Plant Ecology 128:296-308.

Piazena H (1996) The effect of altitude upon the solar UV-B and UV-A irradiance in the tropical Chilean Andes. Solar Energy 57:133-140.

Quaite FE, Sutherland BM, Sutherland JC (1992) Action spectrum for DNA damage in alfalfa lowers predicted impact of ozone depletion. Nature 358:576-578.

Rangel DEN, Braga GUL, Flint SD, Anderson AJ, Roberts DW 
(2004) Variations in UV-B tolerance and germination speed of Metarhizium anisopliae conidia produced on insects and artificial substrates. Journal of Invertebrate Pathology 87:77-83.

Rangel DEN, Braga GUL, Roberts DW (2005) Influence of growth environment on tolerance to UV-B radiation, germination speed, and morphology of Metarhizium anisopliae var. acridum conidia. Journal of Invertebrate Pathology 90:55-58.

Rangel DEN, Butler MJ, Torabinejad J, Anderson AJ, Braga GUL, Day AW, Roberts DW (2006) Mutants and isolates of Metarhizium anisopliae are diverse in their relationships between conidial pigmentation and stress tolerance. Journal of Invertebrate
Pathology 93:170-182.

Shaw DE (1988) Verticillium lecanii a hyperparasite on the coffee rust pathogen in Papua New Guinea. Australasian Plant Pathology 17:1-3.

Spencer DM, Atkey PT (1981) Parasitic effects of Verticillium lecanii on two rust fungi. Transactions of the British Mycological Society 77:535-542.

Vandermeer J, Perfecto I, Liere H (2009) Evidence for hyperparasitism of coffee rust (Hemileia vastatrix) by the entomogenous fungus, Lecanicillium lecanii, through a complex ecological web. Plant Pathology 58:636-641. 